\title{
Erratum to: Investigation about the dependence of spectral diffuse-to-direct-beam irradiance ratio on atmospheric turbidity and solar zenith angle
}

\author{
D. G. Kaskaoutis • H. D. Kambezidis • Z. Tóth
}

Published online: 14 July 2010

(C) Springer-Verlag 2010

Erratum to: Theor Appl Climatol (2007) 89:245-256

DOI 10.1007/s00704-006-0222-Z

The original version of this article unfortunately contained a mistake. The air mass of 1.05 should be corrected to 1.35 throughout the article.

The online version of the original article can be found at http://dx.doi.org/10.1007/s00704-006-0222-z.

D. G. Kaskaoutis $(\bowtie) \cdot$ H. D. Kambezidis

Atmospheric Research Team, Institute for Environmental

Research and Sustainable Development,

National Observatory of Athens,

Lofos Nymphon, Athens, Greece

e-mail:dkask@meteo.noa.gr

D. G. Kaskaoutis

Laboratory of Meteorology, Department of Physics,

University of Ioannina, Ioannina, Greece

Z. Tóth

Hungarian Meteorological Service, Budapest, Hungary 